\title{
A Ricardian Model with Endogenous Comparative Advantage and Endogenous Trade Policy Regimes
}

Wen Li Cheng, Meng-chun Liu, and Xiaokai Yang

CID Working Paper No. 12

April 1999

(C) Copyright 1999 Wen Li Cheng, Meng-chun Liu, Xiaokai Yang, and the President and Fellows of Harvard College
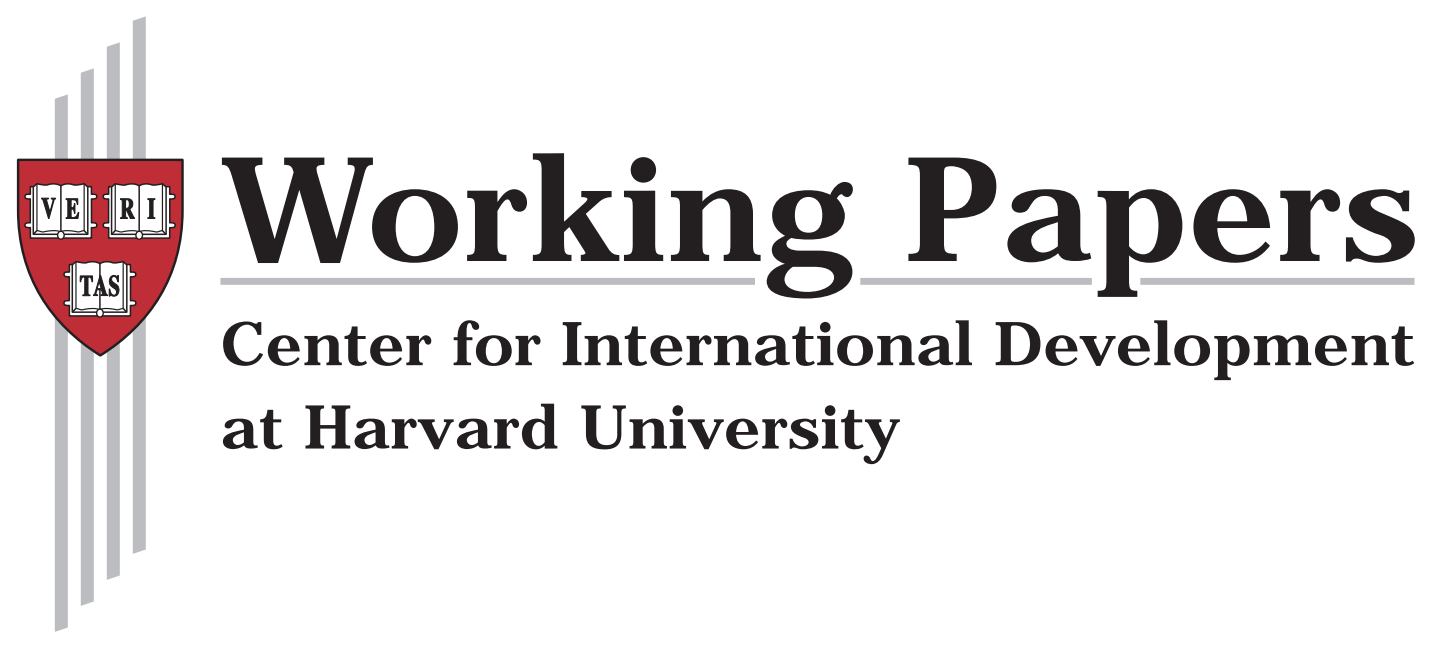


\title{
A Ricardian Model with Endogenous Comparative Advantage and Endogenous Trade Policy Regimes
}

\author{
Wen Li Cheng, Meng-chun Liu, and Xiaokai Yang*
}

\begin{abstract}
This paper develops a general equilibrium model with transaction costs and endogenous and exogenous comparative advantages. In the model, the governments are allowed to choose between tariff war, tariff negotiation, and laissez faire regimes. The model shows that the level of division of labor and the volume of trade increase as transaction conditions improve. In the process of moving to a high level of division of labour, a country may receive more gains from trade even if its terms of trade deteriorate. This is because an expansion of the network size of division of labour can generate productivity gains that outweigh the adverse effect of the terms of trade deterioration. When a high level of division of labor occurs in general equilibrium, if both countries play a Nash tariff game, a tariff war may break out, which can dissipate all the gains from trade. Facing this risk, all governments would prefer trade negotiations to a trade war. A Nash tariff negotiation would result in zero tariff rates. If a medium level of division of labor occurs in general equilibrium, then unilateral tariff protection and unilateral laissez faire policies would coexist. The result provides a plausible story about the evolution of trade policy regimes, and highlights the importance of trade negotiations in achieving trade liberalization.
\end{abstract}

Keywords: inframarginal analysis of trade theory, Ricardo model, dual structure, underdevelopment

JEL codes: O10, $\mathrm{H} 20$

Wen Li Cheng is a senior economist with Law \& Economics Consulting Group. She has written on subjects ranging from the origin of money, economic growth, international trade to government expenditure in New Zealand, network industry regulation in New Zealand and the New Zealand Dairy industry. Her current research interests include equilibrium network of division of labor and industrial organization.

Meng-chun Liu is a research fellow of Institute of Chinese Economy at Taiwan and a Ph.D candidate at Department of Economics, Monash University.

Xiaokai Yang is a Research Fellow at the Center for International Development. His research interests include equilibrium network of division of labor, endogenous comparative advantages, inframarginal analysis of patterns of trade and economic development.

\footnotetext{
*Xiaokai Yang is a corresponding author.
} 


\title{
A Ricardian Model with Endogenous Comparative Advantage and Endogenous Trade Policy Regimes
}

\author{
Wen Li Cheng, Meng-chun Liu, and Xiaokai Yang
}

\section{Introduction}

It is a well-accepted idea that free international trade benefits all countries involved; it is also a well-known fact that hardly any country has always been practicing free trade policies. Why do countries deviate from the free trade regime? Traditional trade theory contends that governments set up trade barriers because of political pressure from interest groups - since imports can pose a threat to some domestic industries, these industries lobby intensely for trade protection (Krueger, 1974, Pincus 1975, Mayer 1984). Other studies suggest that governments are tempted to use trade bargaining to get a larger share of the gains from trade (see, for instance, Morishima, 1989). We can identify three lines of research on trade bargaining. The first line builds on the theory of optimum tariff (Johnson, 1954), and uses bargaining games to model trade negotiations between governments (Mayer 1981, Riezman 1982). The second line of research belongs to the literature of the "new trade theory". It assumes an oligopolistic market structure in international trade, where governments adopt strategic trade policies to gain the economic rent associated with market power (Dixit and Kyle 1985, Krugman 1986, Grossman and Richardson, 1986). The third line of research views international negotiations as a two-level game: at the first level, interest groups lobby for trade policies in their favor, which determines governments' policy preference; at the second level, the negotiation between governments determines the international equilibrium (Grossman and Helpman, 1994, 1995a. 1995b). 
While the existing literature provides insights as to why a particular trade regime may exist, it is silent about how it might evolve and how the equilibrium trade regime might relate to the equilibrium level of international division of labour. The purpose of this paper is to study the equilibrium level of division of labor based on individuals' production and trade decisions, and to examine the general equilibrium implication of the inter-dependence between the level of division of labor and the degree of trade liberalization.

In this paper, we develop a Ricardian model with transaction costs and endogenous comparative advantage ${ }^{1}$. In our model, individuals are consumer-producers, who choose what and then how much to produce and trade. The governments make decisions on trade policies: they can choose to play a Nash tariff game, to have Nash tariff negotiations, or to have laissez faire policies. We shall show that as transaction conditions improve, the equilibrium level of division of labor increases. In the process of moving to a high level of division of labour, a country may receive more gains from trade even if its terms of trade deteriorate. This is because an expansion of the network size of division of labour can generate productivity gains that outweigh the adverse effect of the terms of trade deterioration.

If a high level of division of labor occurs in general equilibrium, each country has some power to affect the terms of trade and has an incentive to impose a tariff. If both countries play a Nash tariff game (i.e., to choose a tariff rate taking the other country's tariff as given), a tariff war may break out, which can dissipate all the gains from trade. Facing this risk, all governments would prefer trade negotiations to a trade war. A Nash tariff negotiation would result in zero tariff rates. If a medium level of division of labor occurs in general equilibrium, i.e., one country

\footnotetext{
${ }^{1}$ Yang and Borland (1991) and Yang (1994) draw the distinction between endogenous and exogenous comparative advantages. Endogenous comparative advantage results from an individual's ex post choice of the pattern and level
} 
is completely specialised in producing one good while the other produces two goods, then unilateral tariff protection and unilateral laissez faire policies would coexist.

The result of the model suggests that the development in the level and pattern of international division of labor may be a driving force behind the evolution of the international trade regime. This may explain the policy transformation in some European governments from Mercantilism to laissez faire in the $18^{\text {th }}$ and $19^{\text {th }}$ century and policy changes in developing countries from protection tariff to trade liberalization and tariff negotiation. ${ }^{2}$ The result also provides an economic rationale for trade negotiations and highlights the importance of trade negotiations in achieving stable trade liberalization.

Two features distinguish our work from other studies on the Ricardian model. First, in our model, the emergence of domestic trade from autarky and emergence of international trade from domestic trade are endogenized (due to the presence of both endogenous and exogenous comparative advantages). Second, we use infra-marginal analysis rather than marginal analysis. Infra-marginal analysis is the combination of a total benefit-cost analysis between corner and interior solutions and a marginal analysis of each corner or interior solution. The use of inframarginal analysis allows us to study discontinuous changes of trade structures.

The rest of this paper is organised as follows. Section 2 presents a simple Ricardian model with transaction costs and endogenous comparative advantage, and discusses the relationship between transaction costs and the equilibrium level of division of labour. Section 3

of specialization in production. Exogenous comparative advantage is generated by ex ante differences (in tastes, in endowments, or in production functions) between individuals.

${ }^{2}$ Mercantilism advocates the use of unilateral tariff as a means of rent seeking in international trade (Ekelund and Tollison, 1981). A shift of trade policy regime from unilateral tariff to trade liberalization is considered by some development economists as a shift from import substitution to export substitution strategy (see, for instance, Balassa, 1980 and Bruton, 1998). 
introduces government policy choices into the model and investigates the endogeneity of trade policy regimes. Section 4 concludes the paper.

\section{A General Equilibrium Ricardian Model}

\subsection{The $2 \times 2$ model}

Consider a world of two countries, country 1 and country 2 , each with $M_{i}(i=1,2)$ individual consumer-producers. Assume that the individuals are ex ante identical within each country and have the following utility function:

$$
U_{i}=\left(x_{i}+k_{i} x_{i}^{d}\right)^{\beta}\left(y_{i}+k_{i} y_{i}^{d}\right)^{1-\beta}
$$

where $x_{i}, y_{i}$ are quantities of goods $\mathrm{X}$ and Y self-provided, and $x_{i}^{d}, y_{i}^{d}$ are quantities of the goods bought from the market. $k_{i}\left(k_{i} \in[0,1]\right)$ is the transaction condition coefficient, which relates to an iceberg type transaction cost: for each unit of good bought, only the fraction $k$ is received by the buyer, $1-k_{i}$ is lost in transit.

The production functions for an individual in country $i$ are

$$
\begin{aligned}
& x_{i}+x_{i}^{s}=\operatorname{Max}\left\{a_{i x}\left(l_{i x}-b\right), 0\right\}, \\
& y_{i}+y_{i}^{s}=\operatorname{Max}\left\{a_{i y}\left(l_{i y}-b\right), 0\right\},
\end{aligned}
$$

where $l_{i x}$ and $l_{i y}$ are respective amounts of labour devoted to producing good X and good Y, and $l_{i x}+l_{i y}=1$. Following Charles Babbage (1832) and Houthakker (1956), we specify an individual-specific fixed learning cost in producing each good, $b$, which may be training costs or costs incurred in a trial-and-error learning process in production. 
Country 1 is assumed to have exogenous comparative advantage in producing good X, that is, $a_{1 x} / a_{1 y}>a_{2 x} / a_{2 y}$. The existence of a fixed learning cost implies that specialising in a single good would increase the utilisation rate of the fixed learning cost and improve labour productivity (Becker, 1981 and Rosen, 1983). The relative productivity advantage obtained through decisions regarding specialisation is referred to as endogenous comparative advantage (Yang, 1994). Endogenous comparative advantage can be the source of the gains from trade when exogenous comparative advantage is absent. When both exogenous and endogenous comparative advantage are present, they interact to determine the pattern of trade ${ }^{3}$.

The decision problem for an individual in country $i$ involves choosing what and how much to produce for self consumption, to sell and to buy from the market. That is, there are six choice variables in the individual's decision problem $x_{i}, x_{i}{ }^{s}, x_{i}{ }^{d}, y_{i}, y_{i}{ }^{s}, y_{i}{ }^{d} \geq 0$. We refer to each individual's choice of what to produce, buy and sell as a configuration, and the combination of all individuals' configurations in both countries that is compatible with market clearing as a market structure, or structure for short.

There are 5 possible structures in our model: structures $\mathrm{A}, \mathrm{D}, \mathrm{Pa}, \mathrm{Pb}$, and C. Structure A is an individual autarkic structure where each individual produces both goods for self consumption (configuration XY), and does not trade with one another. Structure D is a country autarky - there is domestic trade within each country but no trade between the two countries. In this structure, $M_{i x}$ individuals choose to produce X (configuration X/Y), $M_{i y}$ individuals choose to produce $\mathrm{Y}$ (configuration $\mathrm{Y} / \mathrm{X}$ ) in country $i$, where $M_{i x}+M_{i y}=M_{i}$. The two groups of

\footnotetext{
${ }^{3}$ Another way to specify increasing returns to scale in a Ricardian model can be found in Gomory (1994). Gomory's specification is based on the neoclassical dichotomy between consumers and firms, and his model has multiple general equilibria.
} 
individuals trade with each other, but not with individuals from another country. As a result, endogenous comparative advantage is exploited but exogenous comparative advantage is not.

In structure $\mathrm{Pa}$, some individuals in country 1 choose configuration $\mathrm{X} / \mathrm{Y}$ and others choose $\mathrm{Y} / \mathrm{X}$, and all individuals in country 2 choose configuration $\mathrm{Y} / \mathrm{X}$. Structure $\mathrm{Pb}$ is symmetrical to structure $\mathrm{Pa}$. Structures $\mathrm{Pa}$ and $\mathrm{Pb}$ involve asymmetric division of labour - one country is involved in international trade but not domestic trade, while the other county has both domestic and international trade.

In structure $\mathrm{C}$, individuals in country 1 choose configuration $\mathrm{X} / \mathrm{Y}$ and individuals in country 2 choose configuration Y/X. There is no domestic trade in either country, but there is complete specialisation for each individual and for each country, and both endogenous and exogenous comparative advantages are exploited through international trade.

The structures involving international trade are depicted in Figure 1.

Since the individuals' decision variables are discontinuous across structures, we introduce the concept of corner equilibrium. A corner equilibrium is defined as a set of relative prices of traded goods, numbers of individuals choosing different configurations, and the resource allocation in a given structure that satisfy the following conditions: (1) at the set of prices, the utility of each individual in both countries is maximised for the structure; (2) markets clear; and (3) utilities of all ex ante identical individuals within each country are equalised.

The general equilibrium is the corner equilibrium in which each individual uses inframarginal analysis to maximise his utility with respect to all possible configurations. It can be shown that the general equilibrium is Pareto efficient (Zhou, Sun, and Yang 1998).

To solve for the general equilibrium, we first apply the marginal analysis to solve for the corner equilibrium price and quantities for each of the five feasible structures. For instance, 
given structure $\mathrm{Pa}$, the decision problem for individuals in country 1 who choose configuration $\mathrm{X} / \mathrm{Y}$ is :

$$
\begin{array}{lc}
\max _{x_{1} y_{1}, y_{1}^{d}} U_{1(X / Y)}=x_{1}^{\beta}\left(k_{1} y_{1}{ }^{d}\right)^{1-\beta} \\
\text { s.t. } & x_{1}+x_{1}{ }^{s}=a_{1 x}(1-b) \\
& p x_{1}{ }^{s}=y_{1}{ }^{d}
\end{array}
$$

The decision problem for individuals in country 1 who choose configuration $\mathrm{Y} / \mathrm{X}$ is:

$$
\begin{array}{lc}
\max _{x_{1}^{d} y_{1}, y_{1}^{s}} & U_{1(Y / X)}=\left(k x_{1}^{d}\right)^{\beta} y_{1}{ }^{1-\beta} \\
\text { s.t. } & y_{1}+y_{1}{ }^{s}=a_{1 y}(1-b) \\
& y_{1}{ }^{s}=p x_{1}{ }^{d}
\end{array}
$$


Figure 1: Configurations and Structures with International Division of Labor

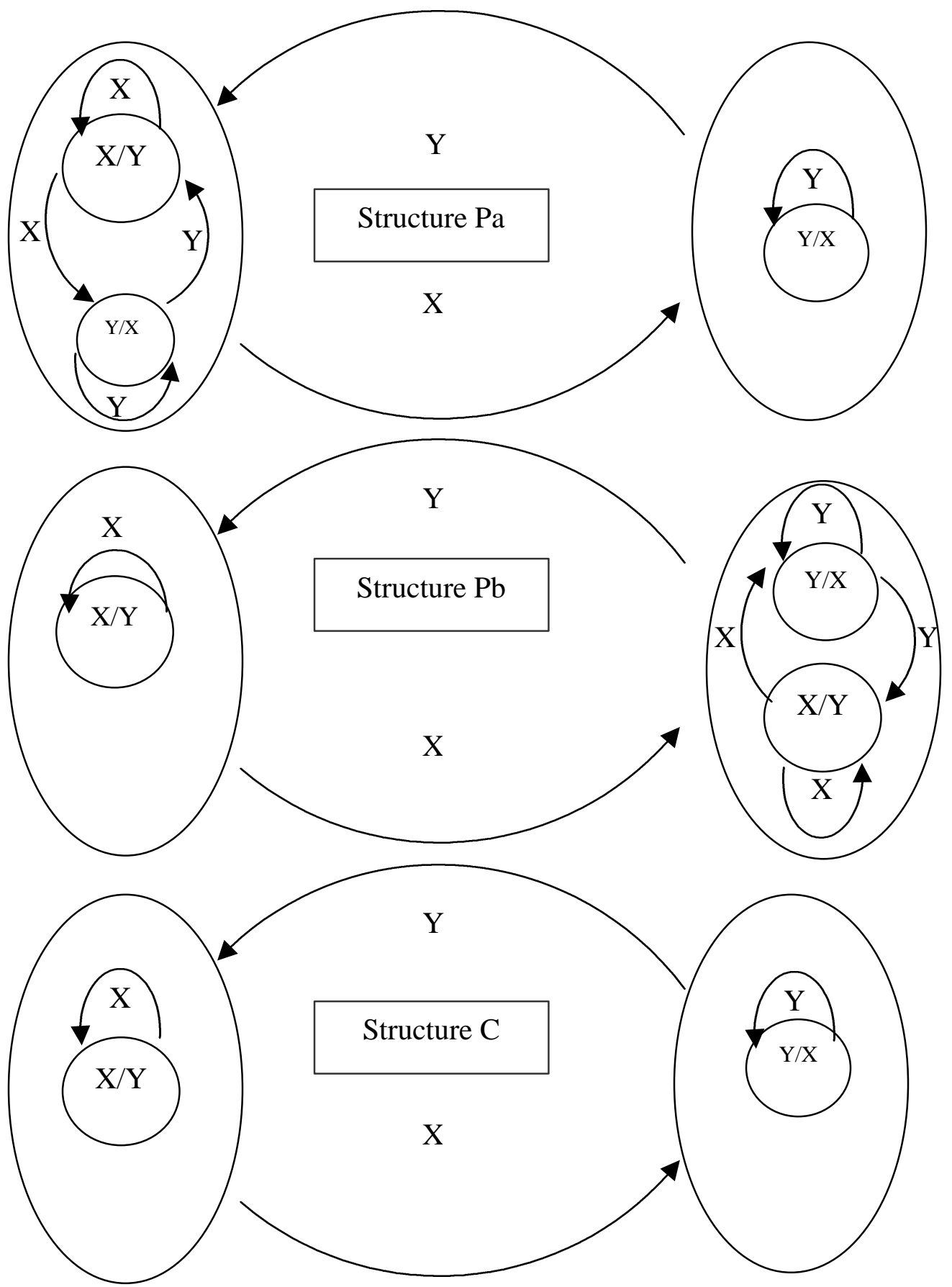

Country 1

Country 2 
Solving the above two decision problems and applying the utility equalisation condition,

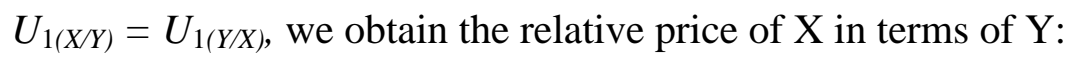

$$
p \equiv p_{x} / p_{y}=\left(a_{1 \mathrm{y}} / a_{1 \mathrm{x}}\right) k_{1}^{2 \beta-1}
$$

We then solve the decision problem for individuals in country 2 , which is

$$
\begin{array}{ll}
\max _{x_{2}{ }^{d} y_{2}, y_{2}{ }^{s}} U_{2} & =\left(k x_{2}{ }^{d}\right)^{\beta} y_{2}{ }^{1-\beta} \\
\text { s.t. } & y_{2}+y_{2}{ }^{s}=a_{2 y}(1-b) \\
& y_{2}{ }^{s}=p x_{2}{ }^{d}
\end{array}
$$

Inserting demand and supply functions from the above decisions into the market clearing condition, we can solve for $M_{1 \mathrm{x}}$ and $M_{1 \mathrm{y}}$ which are the proportions of individuals in country 1 who choose configuration $\mathrm{X} / \mathrm{Y}$ and configuration $\mathrm{Y} / \mathrm{X}$, respectively.

\begin{tabular}{|c|c|c|c|}
\hline \multirow[t]{2}{*}{ Structure } & \multirow{2}{*}{$\begin{array}{c}\text { Relative Price } \\
P_{x} / p_{y}\end{array}$} & \multicolumn{2}{|c|}{ Per Capita Real Income (Utility) } \\
\hline & & Country 1 & Country 2 \\
\hline$A$ & & $\begin{array}{c}B a_{1 x}{ }^{\beta} a_{1 y}{ }^{1-\beta}(1-2 b), \\
\mathrm{B} \equiv \beta^{\beta}(1-\beta)^{1-\beta}\end{array}$ & $\begin{array}{c}B a_{2 \mathrm{x}}{ }^{\beta} a_{2 \mathrm{y}}{ }^{1-\beta}(1-2 b), \\
\mathrm{B} \equiv \beta^{\beta}(1-\beta)^{1-\beta}\end{array}$ \\
\hline$D$ & $\begin{array}{c}\left(a_{\mathrm{iy}} / a_{\mathrm{ix}}\right) k_{\mathrm{i}}^{2 \beta-1}, \\
i=1,2\end{array}$ & $D_{1} \equiv B k_{1}^{2 \beta(1-\beta)} a_{1 x}^{\beta} a_{1 y}^{1-\beta}(1-b)$ & $D_{2} \equiv B k_{2}^{2 \beta(1-\beta)} a_{2 x}^{\beta} a_{2 y}^{1-\beta}(1-b)$ \\
\hline$P_{a}$ & $\left(a_{1 \mathrm{y}} / a_{1 \mathrm{x}}\right) k_{1}^{2 \beta-1}$ & $D_{1}$ & $B k_{2}{ }^{\beta} a_{2 y}(1-b)\left(k_{1}{ }^{1-\beta} a_{1 \mathrm{x}} / a_{1 \mathrm{y}}\right)^{\beta}$ \\
\hline$P_{b}$ & $\left(a_{2 \mathrm{y}} / a_{2 \mathrm{x}}\right) k_{2}^{2 \beta-1}$ & $B k_{1}^{1-\beta} a_{1 x}(1-b)\left(k_{2}^{2 \beta-1} a_{2 y} / a_{2 x}\right)^{1-\beta}$ & $D_{2}$ \\
\hline$C$ & $\frac{\beta}{1-\beta} \frac{a_{2 y} M_{2}}{a_{1 x} M_{1}}$ & $\beta a_{1 \mathrm{x}}{ }^{\beta} a_{2 \mathrm{y}}{ }^{1-\beta}(1-b) k_{1}{ }^{1-\beta}\left(M_{2} / M_{1}\right)^{1-\beta}$ & $(1-\beta) a_{1 \mathrm{x}}{ }^{\beta} a_{2 \mathrm{y}}{ }^{1-\beta}(1-b) k_{2}{ }^{\beta}\left(M_{1} / M_{2}\right)^{\beta}$ \\
\hline
\end{tabular}

Following a similar procedure, we solve for the corner equilibria for other structures. The results are summarised in Table 1.

\section{Table 1: Five Walrasian Corner Equilibria in the Extended Ricardo Model}

Given a set of market prices, an individual would choose a configuration that generates a utility level that is no lower than the utility levels associated with other alternative 
configurations. The condition that all individuals' utilities are maximised across all possible configurations defines a parameter subspace within which the structure is the general equilibrium. The general equilibria and their corresponding parameter subspaces are summarised in Table 2.

Table 2: Walrasian Equilibrium and Its Inframarginal Comparative Statics

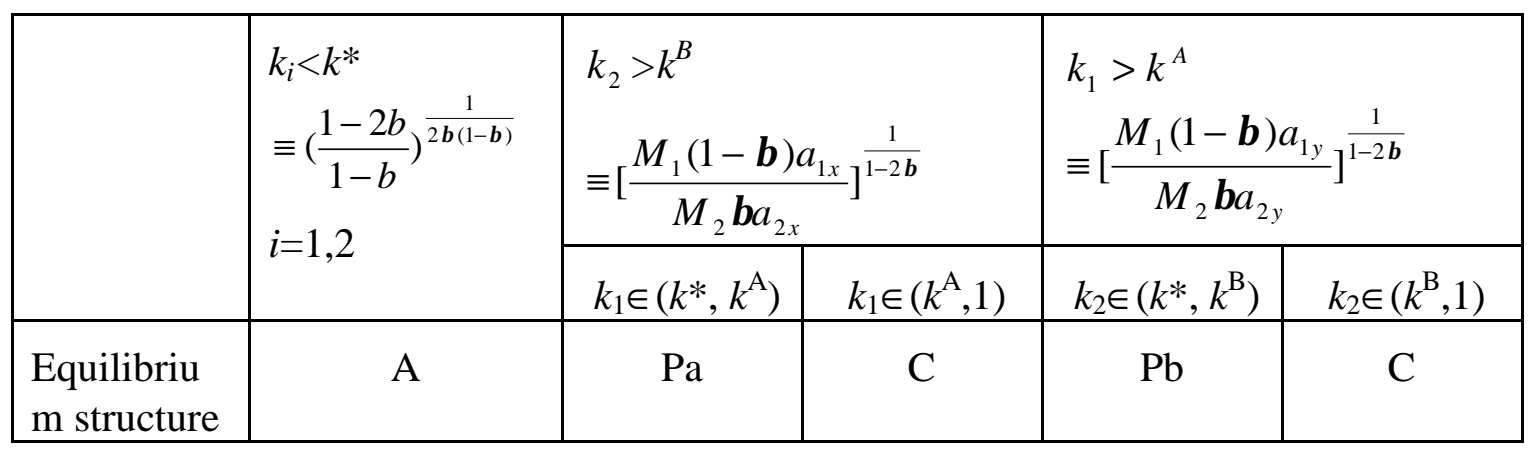

$k^{*} \equiv\left(\frac{1-2 b}{1-b}\right)^{\frac{1}{2 \beta(1-\beta)}}, k^{\mathrm{A}} \equiv\left[\frac{M_{1}}{M_{2}} \frac{(1-\beta) a_{1 y}}{\beta a_{2 y}}\right]^{\frac{1}{1-2 \beta}}, k^{\mathrm{B}} \equiv\left[\frac{M_{1}}{M_{2}} \frac{(1-\beta) a_{1 x}}{\beta a_{2 x}}\right]^{\frac{1}{1-2 \beta}}$.

We illustrate the results in Table 2 using the case of structure Pa. For structure Pa to occur in equilibrium, the following conditions must hold: $k_{2}>\left[\frac{M_{1}(1-\beta) a_{1 x}}{M_{2} \beta a_{2 x}}\right]^{\frac{1}{1-2 \beta}}$, and $k_{1} \in\left(k^{*}\right.$, $\left.k^{\mathrm{A}}\right)$. These conditions imply that $\left.M_{1} / M_{2} \in\left(k_{1}{ }^{1-2 \beta} \beta a_{2 y} / a_{1 \mathrm{y}}(1-\beta), k_{2}{ }^{1-2 \beta}(1-\beta) a_{2 y} / \beta a_{1 y}\right)\right)$, which holds only if $k_{2} / k_{1}>\left\{[\beta /(1-\beta)]^{2}\left(a_{2 x} a_{2 y} / a_{1 x} a_{1 y}\right)\right\}^{1 /(1-2 \beta)}$. In other words, structure Pa occurs in equilibrium only if the transaction efficiency in country 2 relative to country 1 is sufficiently high given other parameters.

From Table 2 it is clear that when a change in $k_{1}$ or $k_{2}$ exceeds certain threshold values, the equilibrium jumps discontinuously. We refer to this analysis which investigates how equilibrium solutions change discontinuously in response to a change in parameter values as 
infra-marginal comparative statics. The results in Table 2 suggest that transaction conditions determine the equilibrium level of division of labor - as transaction conditions improve, the equilibrium level of division of labor jumps from autarky to partial division of labor (structure $\mathrm{Pa}$ or $\mathrm{Pb}$ ), then to the complete division of labor (structure $\mathrm{C})$. In the transitional structure (Pa or $\mathrm{Pb})$, the country which produces two goods receives no gains from trade.

The infra-marginal comparative statistics also allow us to study how productivity levels change as the general equilibrium structure shifts. If the general equilibrium structure is the individual autarky, the equalisation of the marginal rate of substitution and the marginal rate of transformation for each individual means that the equilibrium aggregate productivity is below the production possibility frontier (PPF). As the level of division of labour increases with the improvement of transaction conditions, the equilibrium aggregate productivity moves closer to the PPF.

Since the general equilibrium is Pareto optimal, we can also say that if transaction conditions are very poor, the Pareto optimum is not associated with the PPF because of the tradeoff between gains from (endogenous and exogenous) comparative advantages and transaction costs $^{4}$. As transaction conditions improve, the Pareto optimum moves closer to the PPF. This result can be used to explore development implications of transaction conditions and the relationship between trade dependence and economic development - improvements in transaction conditions lead to an expansion of the network of trade, which increases the equilibrium aggregate productivity.

Summarising the above discussion, we have:

\footnotetext{
${ }^{4}$ Zhou, Sun, and Yang (1998) prove that a general equilibrium for a broad class of models with consumer-producers and endogenous and exogenous comparative advantages exists if the set of individuals is a continuum and that the general equilibrium is Pareto optimal.
} 
Proposition 1: If transaction conditions are very poor in both countries, the general equilibrium is individual autarky where no domestic or international trade takes place. As one country improves its transaction conditions, the general equilibrium jumps to partial division of labour (structure $\mathrm{Pa}$ or $\mathrm{Pb}$ ) where this country completely specialises and engage in international trade, and the other country produces two goods and engage in both domestic and international trade. All gains from trade go to the country that completely specialises. If the transaction conditions in both countries improve sufficiently, the equilibrium jumps to complete international division of labour, and the two countries share the gains from trade. In this process, the equilibrium aggregate productivity converges to the aggregate production possibility frontier.

Another interesting result we derive from the infra-marginal comparative statics is that even if a country experiences a terms of trade deterioration, it may receive more gains from trade. For instance, suppose $k_{1} \in\left(k^{*}, k^{\mathrm{A}}\right), k_{2}>k^{*}$, and $k_{2}>k^{\beta}$. Under these conditions, the general equilibrium is structure $\mathrm{Pa}$ and the equilibrium relative price is $p_{\mathrm{x}} / p_{\mathrm{y}}=\left(a_{1 \mathrm{y}} / a_{1 \mathrm{x}}\right) k_{1}{ }^{2 \beta-1}$ (see Table 2). Now suppose that the transaction condition in country 1 improves, such that $k_{1} \in\left(k^{\mathrm{A}}, 1\right)$, the equilibrium jumps to structure $\mathrm{C}$ where the relative price is $p_{\mathrm{x}} / p_{\mathrm{y}}=\frac{\beta}{1-\beta} \frac{a_{2 y} M_{2}}{a_{1 x} M_{1}}$. It can be shown that within the parameter subspace defined by $\frac{\beta}{1-\beta} \frac{a_{2 y} M_{2}}{a_{1 x} M_{1}}>\left(a_{1 \mathrm{y}} / a_{1 \mathrm{x}}\right) k_{1}^{2 \beta-1}$, country 1's terms of trade deteriorates as the equilibrium shifts from structure Pa to C. Since country 1's utility in structure $\mathrm{C}$ is higher than in structure $\mathrm{Pa}$, we conclude that a deterioration in a country's terms of trade may be associated with an increase of gains from trade received by the country. The logic behind this result is that a move towards a higher level of division of labour generates 
productivity gains. The productivity gains may more than compensate for the deterioration in the terms of trade. Hence, it may be misleading to claim that a deterioration in a country's terms of trade necessarily reduces this country's gains from trade. There has been a lot of debate about whether developing economies have suffered from worsening terms of trade (Morgan, 1970). Our analysis suggests that the emphasis on the terms of trade effect may need to be shifted - a more important issue for economic development is the expansion of the network of division of labour. In the process of the network expansion, a country's terms of trade may deteriorate, but its productivity will improve. As long as the productivity improvement outpaces the terms of trade deterioration, the country will receive more gains from trade.

So far our focus has been on the division of labour, or, the source of the gains from trade. In the next section, we examine the distribution of the gains. In particular we look at what strategies governments may use in order to obtain more gains from trade.

\section{Endogenous Trade Policy Regime}

It is assumed that the governments can choose from three trade policy regimes: a Nash tariff game where each government chooses its own tariff rate, taking the other country's tariff rate as given, Nash tariff bargaining, and laissez faire.

Since the welfare effect of tariff is different between various trade structures, we examine each structure separately, starting with structure $\mathrm{C}$, and then moving on to structures $\mathrm{Pa}$ and $\mathrm{Pb}$.

\subsection{Structure C: Complete International Division of Labor}

Assumed that the government in each country can impose tariff on imported goods to maximise its citizen's welfare. Tariff revenue is equally distributed among the domestic buyers 
of the imported goods. In structure $\mathrm{C}$, the decision problems for individuals in country 1 and in country 2 are:

$$
\begin{aligned}
& \max _{x_{1} y_{1}^{d}} U_{1}=x_{1}^{\beta}\left(k_{1} y_{1}^{d}\right)^{1-\beta}, \quad \quad \max _{x_{2}^{d} y_{2}} U_{2}=\left(k_{2} x_{2}^{d}\right)^{\beta} y_{2}^{1-\beta}, \\
& \text { s.t. } \quad p_{x} x_{1}^{s}+R_{1}=p_{y}\left(1+t_{1}\right) y_{1}^{d}, \quad \text { s.t. } \quad p_{y} y_{2}^{s}+R_{2}=p_{x}\left(1+t_{2}\right) x_{1}^{d} \text {, } \\
& x_{1}+x_{1}^{s}=a_{1 x}(1-b), \quad y_{1}+y_{1}^{s}=a_{2 y}(1-b),
\end{aligned}
$$

where $t_{i}$ is the tariff rate in country $i$, and $R_{i}$ is the tariff revenue received by an individual in country $i$.

Solving the decision problems, we obtained supply and demand functions for good $\mathrm{X}$ and good Y, and the average tariff revenue transferred to each individual in country 1 and country 2 :

$$
\begin{array}{ll}
x_{1}^{\mathrm{s}}=(1-\beta) a_{1 \mathrm{x}}(1-b) /\left(1+\beta t_{1}\right), \quad y_{1}^{\mathrm{d}}=\left(p_{\mathrm{x}} / p_{\mathrm{y}}\right)(1-\beta) a_{1 \mathrm{x}}(1-b) /\left(1+\beta t_{1}\right), & R_{1}=t_{1} p_{y} y_{1}^{d}, \\
y_{2} \mathrm{~s}=\beta a_{2 \mathrm{y}}(1-\mathrm{b}) /\left[1+(1-\beta) t_{2}\right], \quad x_{2}{ }^{\mathrm{d}}=\left(p_{\mathrm{y}} / p_{\mathrm{x}}\right) \beta a_{2 \mathrm{y}}(1-\mathrm{b}) /\left[1+(1-\beta) t_{2}\right], & R_{2}=t_{2} p_{x} x_{2}^{d},
\end{array}
$$

Using the market clearing condition for good $\mathrm{X}$, we can solve for the relative price of $\operatorname{good} \mathrm{X}$ in terms of good $\mathrm{Y}$ :

$$
\frac{p_{y}}{p_{x}}=\frac{M_{1}}{M_{2}} \frac{a_{1 x}(1-\beta)}{a_{2 y} \beta} \frac{(1-\beta) t_{2}+1}{\left(\beta t_{1}+1\right)} .
$$

Substituting the demand and supply functions and the relative price into the utility functions, we get the equilibrium levels of utilities for individuals in the two counties:

$$
\begin{aligned}
& u_{1}\left(t_{1}, t_{2}\right)=\beta(1-b)\left[\frac{\left(1+t_{1}\right) a_{1 x}}{1+\beta t_{1}}\right]^{\beta}\left[\frac{a_{2 y} k_{1}}{1+(1-\beta) t_{2}}\right]^{1-\beta}\left(\frac{M_{2}}{M_{1}}\right)^{1-\beta}, \\
& u_{2}\left(t_{1}, t_{2}\right)=(1-\beta)(1-b)\left[\frac{\left(1+t_{2}\right) a_{2 y}}{1+(1-\beta) t_{2}}\right]^{1-\beta}\left[\frac{a_{1 x} k_{2}}{1+\beta t_{1}}\right]^{\beta}\left(\frac{M_{1}}{M_{2}}\right)^{\beta} .
\end{aligned}
$$

We now look at how governments may choose from different trade policy regimes.

\section{Nash tariff game}


Differentiation of the two expressions with respect to $t_{i}$ yields:

$$
\begin{array}{ll}
\frac{\partial u_{1}}{\partial t_{1}}=\frac{\beta(1-\beta)}{\left(1+t_{1}\right)\left(1+\beta t_{1}\right)} u_{1}>0, & \frac{\partial u_{1}}{\partial t_{2}}<0, \\
\frac{\partial u_{2}}{\partial t_{2}}=\frac{\beta(1-\beta)}{\left(1+t_{2}\right)\left[1+(1-\beta) t_{2}\right]} u_{2}>0, & \frac{\partial u_{2}}{\partial t_{1}}<0 .
\end{array}
$$

The above four inequalities suggest that taking the other country's tariff rate as given, each country can improve its citizens' welfare by imposing a tariff. Thus the governments could play a Nash tariff game but would not adopt laissez faire trade policies. However, if the governments in the two countries do play a Nash tariff game, the above four inequalities imply that in Nash equilibrium each country would impose a tariff to such a high level that individuals in the other country is just indifferent between participating in international trade and autarky. The Nash equilibrium tariff rates are determined by equalization conditions between utility in structure D and that in structure $\mathrm{C}$ :

$$
\begin{aligned}
& t_{1}=\beta^{-1}\left[\frac{(1-\beta) a_{1 x} M_{1}}{\beta a_{2 x} M_{2}} k_{2}{ }^{1-2(1-\beta)}\left(\frac{1+t_{2}}{1+(1-\beta) t_{2}}\right)^{\frac{1-\beta}{\beta}}-1\right], \text { and } \\
& t_{2}=(1-\beta)^{-1}\left[\frac{\beta a_{2 y} M_{2}}{(1-\beta) a_{1 y} M_{1}} k_{2}^{1-2 \beta}\left(\frac{1+t_{1}}{1+\beta t_{1}}\right)^{\frac{\beta}{1-\beta}}-1\right] .
\end{aligned}
$$

The solution of $t_{1}$ and $t_{2}$ are implicitly given by the two equations.

In other words, if the each governments uses tariff to compete for a larger share of the gains from trade, a tariff war will break out which can exhaust all the gains from trade. This is an example of the Prisoner's dilemma.

\section{Nash tariff negotiation}

Alternatively, the two governments can play a Nash bargaining game, that is, they can negotiate over tariff rates. The Nash tariff negotiation maximizes the Nash product, which is the 
product of the gains from trade received by individuals in each country. The gains from trade are measured by the difference in utility between participating in trade (structure $\mathrm{C}$ in this case) and staying in a structure with only domestic trade (structure D). The Nash tariff negotiation equilibrium is given by the solution of the following problem:

$$
\max _{t_{1}, t_{2}} V=\left[u_{1}\left(t_{1}, t_{2}\right)-u_{1}(D)\right]\left[u_{2}\left(t_{1}, t_{2}\right)-u_{2}(D)\right]
$$

The first order conditions for this problem yield $\left(t_{1}+1\right)\left(t_{2}+1\right)=1$, which gives the optimal tariff rates, $t_{1}=t_{2}=0$. In other words, the Nash tariff negotiation generates trade liberalization.

The result of a tariff negotiation is in sharp contrast with the result of a Nash tariff game with the latter leading to complete dissipation of the gains from trade because of the prisoners' dilemma. This provides an explanation as to why free trade may not be achieved through the market mechanism despite the fact that free trade is beneficial for all countries. It also suggests that trade negotiations may be essential for trade liberalization and for the full exploitation of the gains from trade.

If the two governments can choose between the Nash tariff war and the Nash tariff negotiation, they will certainly choose the latter. Hence, if structure $\mathrm{C}$ occurs in equilibrium and the governments are allowed to choose policy regimes, the general equilibrium trade policy will be free trade resulted from a Nash tariff negotiation.

The Nash bargaining game does not explicitly spell out the bargaining process, rather, it follows the axiomatic approach. It is proven that there is a unique bargaining solution that satisfies the four basic axioms: invariance to equivalent utility representations, symmetry, independence of irrelevant alternatives, and Pareto efficiency ${ }^{5}$. This bargaining solution maximises the Nash product, which is the product of the players' gains in utility over the 
disagreement outcome. Although no risk is specified in this game, the players' attitude towards risk "plays a central role" (Osborne and Rubinstein, 1990, p.10). As long as there exists some uncertainty about other players' behavior, there is a chance that the negotiation would break down, thus each player intends to maximise his expected utility gain in the negotiation. The Nash product can be interpreted as a player's expected utility gain, with the probability of reaching an agreement being approximated by the utility gains of the other player(s). For this reason, Nash (1950) contends that the Nash bargaining solution is the outcome of a noncooperative game despite the fact that the gains are shared fairly among players.

\subsection{Structures Pa and Pb: Partial International Division of Labor}

We now turn to the structures with partial international division of labor, structures $\mathrm{Pa}$ and $\mathrm{Pb}$, to examine the choices of trade policies. Since the two structures are symmetrical, we only have to consider one of them, say, structure Pa.

In country 1 , the decision problem for an individual specialising in good $\mathrm{X}$ that that for an individual specializing in good $\mathrm{Y}$ are, respectively

$$
\begin{aligned}
& \operatorname{Max}: u_{1}(x / y)=x_{1}^{\beta}\left(k_{1} y_{1}^{d}\right)^{1-\beta}, \\
& \text { s.t. } \quad x_{1}^{s}+x_{1}=a_{1 x}(1-b), p_{x} x_{1}{ }^{s}+R_{1}=p_{y} y_{1}^{d}+\left(1+t_{1}\right) p_{y} y_{2}{ }^{d}, \\
& \text { Max: } u_{1}(y / x)=\left(k_{1} x_{1}^{d}\right)^{\beta} y_{1}^{1-\beta}, \\
& \text { s.t. } \quad y_{1}^{s}+y_{1}=a_{1 y}(1-b), \quad p_{x} x_{1}^{d}=p_{y} y_{1}^{s},
\end{aligned}
$$

By assumption, only buyers of imported goods receive transfer from tariff revenue, the amount of transfer received by an individual specialising in good $\mathrm{X}$ is $R_{1}$. The solution of the decision problem is

\footnotetext{
${ }^{5}$ See Osborne and Rubinstein, 1990, Chapter 2.
} 


$$
\begin{aligned}
& x_{1}^{s}=(1-\beta) a_{1 x}(1-b)-\beta \frac{R_{1}}{p_{x}}, \quad y_{1}^{d}=(1-\beta)\left[a_{1 x}(1-b) \frac{p_{x}}{p_{y}}+\frac{R_{1}}{p_{y}}\right], \\
& y_{1}^{s}=\beta a_{1 y}(1-b), R_{1}=t_{1} p_{y} y_{2}^{d} /\left(1+t_{1}\right)=t_{1} p_{y}\left[M_{2} \beta a_{2 y}(1-b)\right] /\left[M_{x}\left(1+t_{1}\right)\right] .
\end{aligned}
$$

Similarly we can solve the decision problem for individuals in country 2. Applying the utility equalization condition and the market clearing condition for either good, we obtain the corner equilibrium in structure $\mathrm{Pa}$ :

$$
\begin{aligned}
& \frac{p_{x}}{p_{y}}=\frac{a_{1 y}}{a_{1 x}} k_{1}^{2 \beta-1}-\frac{t_{1} a_{1 y} a_{2 y} M_{2}\left[\beta+(1-\beta) k_{1}^{2 \beta-1}\right]}{a_{1 x}\left(a_{1 y} M_{1}+M_{2} a_{2 y}\right)\left(1+t_{1}\right)}, \\
& M_{1 x}=\frac{\beta\left[M_{2} a_{2 y}+a_{1 y} M_{1}\right]}{a_{1 y}\left[(1-\beta) k_{1}^{2 \beta-1}+\beta\right]}, M_{1 y}=M_{1}-M_{1 x}, y_{2}^{d}=\left[M_{2} \beta a_{2 y}(1-b)\right] / M_{x}, \\
& u_{1}=\beta^{\beta}(1-\beta)^{1-\beta}(1-b) k_{1}^{\beta} a_{1 y}\left(\frac{p_{y}}{p_{x}}\right)^{\beta} . \\
& u_{2}=\frac{\left(k_{2} \beta\right)^{\beta}\left[(1-\beta)\left(1+t_{2}\right)\right]^{1-\beta}}{1+(1-\beta) t_{2}}\left[\frac{p_{y}}{\left(1+t_{1}\right) p_{x}}\right]^{\beta} a_{2 y}(1-b)
\end{aligned}
$$

From the equilibrium solution, we obtain

$$
\frac{\partial u_{1}}{\partial t_{1}}=\beta^{\beta}(1-\beta)^{1-\beta} k_{1}^{2 \beta(1-\beta)}(1-b) a_{1 y}\left[\left(\frac{p_{y}}{p_{x}}\right)^{1+\beta}\left(-\beta \frac{\partial\left(p_{x} / p_{y}\right)}{\partial t_{1}}\right)\right]>0,
$$

where $\frac{\partial\left(p_{x} / p_{y}\right)}{\partial t_{1}}=-\frac{a_{1 y} a_{2 y} M_{2}\left[\beta+(1-\beta) k^{2 \beta-1}\right]}{a_{1 x}\left(M_{1} a_{1 y}+M_{2} a_{2 y}\right)}<0$.

Clearly, country 1 would not choose free trade policies. If it plays a Nash tariff game, it would want its tariff rate to be as high as possible. But since

$$
\frac{\partial u_{2}}{\partial t_{1}}=-\beta^{\beta+1}(1-\beta)^{1-\beta}(1-b) k_{2}{ }^{\beta} a_{1 x}^{\beta} a_{2 y}\left[\frac{p_{y}}{\left(1+t_{1}\right) p_{x}}\right]^{\beta+1}\left[\frac{p_{x}}{p_{y}}+\left(1+t_{1}\right) \frac{\partial\left(p_{x} / p_{y}\right)}{\partial t_{1}}\right]<0,
$$


country 1 needs to ensure that its tariff rate is not so high as to drive country 2 out of international trade. Thus, the optimum tariff rate for country 1 is determined by the utility equalisation between structure $\mathrm{Pa}$ and structure $\mathrm{D}$ for individuals in country 2 , which (after some algebraic simplification) is

$$
\frac{a_{1 y}}{a_{1 x}} k_{1}^{2 \beta-1}-\frac{a_{2 y}}{a_{2 x}} \frac{k_{2}^{2 \beta-1}}{1+t^{*}}-\frac{t^{*} M_{2} a_{1 y} a_{2 y}\left[\beta+(1-\beta) k_{1}^{2 \beta-1}\right]}{a_{1 x}\left(a_{1 y} M_{1}+a_{2 y} M_{2}\right)\left(1+t^{*}\right)}=0,
$$

where $t^{*}$ is the optimal $t_{1}$ imposed by country 1 .

Since $\partial u_{2} / \partial t_{2}<0$, the optimum tariff rate for country 2 is zero.

Therefore, if structure $\mathrm{Pa}$ is the equilibrium structure, the result of a Nash tariff game would be the coexistence of an unilateral protection tariff imposed by country 1 (which produces both goods $\mathrm{X}$ and $\mathrm{Y}$ ) and unilateral laissez faire policy by country 2 .

In a Nash tariff game, country 1 gets most the gains from trade. Since a Nash tariff negotiation would mean sharing the gains from trade, country 1 does not have an incentive to participate in a trade negotiation. Thus even if the governments in both countries are allowed to choose between the Nash tariff game and Nash tariff negotiation, the Nash tariff negotiation would not be chosen by country 1 . As a result, the equilibrium trade policy regime would feature the coexistence of unilateral protection tariff and unilateral laissez faire trade policies.

We may draw the distinction between exogenous transaction cost coefficient $1-k$ and endogenous transaction costs caused by the deadweight loss of tariff. Exogenous transaction costs are present before individuals have made their decisions. Endogenous transaction costs are caused by conflicts between individual decisions. Following the method used in section 2, we can prove that as exogenous transaction cost coefficient $1-k$ decrease, the general equilibrium jumps from country autarky to the partial division of labor, where unilateral protection tariff and 
unilateral laissez faire coexist, then to the complete division of labor, where tariff negotiation generates bilateral free trade. In the transitional period with partial division of labor, endogenous transaction costs are caused by trade conflicts between the trading countries.

There are two ways of getting more gains from trade in the transitional period. One is to improve domestic transaction conditions so that the equilibrium jumps to the complete division of labor, which ensures bilateral incentives for tariff negotiation, which leads to trade liberalization. The other is that the larger country imposes a stiff tariff to get greater gains from trade at the cost of the trading partner. The first way is to create a larger share by enlarging the pie; the second way is to let one of trading country enjoy a larger share of a smaller pie.

We can summarise the above discussion as follows.

Proposition 2: As exogenous transaction conditions improve, the equilibrium jumps from autarky to the partial international division of labor where the coexistence of unilateral protection tariff and unilateral laissez faire generates endogenous transaction costs, then to the complete international division of labor where tariff negotiations lead to free trade and eliminates endogenous transaction costs.

\section{Conclusion}

In this paper, we have introduced transaction costs and endogenous comparative advantage into the Ricardian model. We have also examined governments' choices of different trade policy regimes. An interesting result of this paper is that the equilibrium trade policy regime is intimately related to the level of international division of labor. At a high level of international division of labor, countries would participate in Nash tariff negotiations, which would lead to free trade. If the level of division of labor is at a level such that one country produces both goods 
and determines the terms of trade, then at equilibrium, unilateral tariff and unilateral free trade would coexist. The model provides a plausible story about how a trade policy regime might evolve, and an explanation for the changing tides of trade policy stances in developing countries. Another interesting result of this paper is that a deterioration in a country' terms of trade may be associated with an increase in the gains from trade received by the country.

An obvious extension of the model is to introduce more goods and/or more countries. In addition, the specification of the model may be varied to study other interesting issues. For instance, if we assume different transaction costs for domestic and international trade, and allow both constant returns and increasing returns in production, then structure $\mathrm{D}$ which involves only domestic division of labour may occur in equilibrium. The country which has relatively poor transaction conditions may have a dual economy in which some individuals completely specialize and the others choose autarky (Zhou, Sun, and Yang 1998). This variation may be used to study underemployment in developing countries. 


\section{References}

Babbage, C. (1832), On the Economy of Machinery and Manufactures, 4th enlarged edition of 1835, reissued in 1977, New York, M. Kelly.

Balassa, B. (1980), The Process of Industrial Development and Alternative Development Strategies, Princeton University, International Finance Section, Essays in International Finance, No. 141.

Becker, G. (1981), A Treatise on the Family, Cambridge, Massachusetts, Harvard University Press.

Bruton, Henry (1998), “A Reconsideration of Import Substitution,” Journal of Economic Literature, 36, 903-36.

Dixit, Avinash K and Albert S. Kyle (1985), "The Use of Protection and Subsidies for Entry Promotion and Deterrence." American Economic Review, 75, 139-52.

Ekelund, Robert, and Robert Tollison (1981), Merchantilism as an Rent-seeking Society, College Station, TX, Texas A \& M University Press.

Gomory, Ralph E. (1994), "A Ricardo Model with Economies of Scale," Journal of Economic Theory, 62, 394-419.

Grossman, Gene M. and J. David Richardson (1986), "Strategic Trade Policy: A Survey of the Issues and Early Analysis." In Robert E. Baldwin and J. David Richardson, eds., International Trade and Finance, 3rd ed., 95-113. Boston: Little, Brown.

Grossman Gene M. and Helpman, Elhanan (1994), "Protection For Sale," American Economic Review, 84, 833-50.

Grossman Gene M. and Helpman, Elhanan (1995a), "The Politics of Free-Trade Agreements," American Economic Review, 85(4),667-690.

Grossman Gene M. and Helpman, Elhanan (1995b), "Trade Wars and Trade Talks," Journal of Political Economy, 1995, 103(4), 675-708.

Houthakker, M. (1956): "Economics and Biology: Specialization and Speciation", Kyklos, 9: 181-89.

Johnson, Harry G. (1954), “Optimum Tariff and Retaliation,” Review of Economic Studies, 21(2), 142-53.

Krueger, Anne O. (1974), "The Political Economy of Rent-seeking Society," American Economic Review, 64, 291-303.

Krugman, Paul R. (1986), Strategic Trade Policy and the New International Economics, ed., Cambridge: MIT Press.

Mayer, Wolfgang (1981), "Theoretical Considerations on Negotiated Tariff Adjustments." Oxford Economic Papers, 33, 135-53

Mayer, Wolfgang (1984), "Endogenous Tariff Formation,” American Economic Review, 74, 970-85. 
Morishima, Michio (1989), Ricardo's Economics: A general equilibrium theory of distribution and growth, Cambridge: Cambridge University Press.

Nash, J. F. (1950), “The Bargaining Problem,” Econometrica, 18, 115-62.

Osborne, Martin J. and Rubinstein, Ariel (1990), Bargaining and Markets, San Diego: Academic Press, Inc.

Pincus, Jonathan J. (1975), "Pressure Groups and the Pattern of Tariffs," Journal of Political Economy, 83, 757-78.

Pomfret, Richard (1992), "International Trade Policy with Imperfect Competition," Special Papers in International Economics, No. 17, August, 1992.

Riezman, Raymond (1982), "Tariff Retaliation from a Strategic Viewpoint," Southern Economic Journal, 48, 583-93.

Rosen, S. (1983): "Specialization and Human Capital", Journal of Labor Economics, 1, 43-49.

Wen, M. (1998): “An Analytical Framework of Consumer-Producers, Economies of Specialisation and Transaction Costs," in K. Arrow, Y-K. Ng, X. Yang eds. Increasing Returns and Economic Analysis, London, Macmillan.

Yang, X. (1994), "Endogenous vs. Exogenous Comparative Advantages and Economies of Specialization vs. Economies of Scale", Journal of Economics, 60, 29-54.

Yang, X. and Borland, J. (1991): "A Microeconomic Mechanism for Economic Growth". Journal of Political Economy, 99: 460-82.

Zhou, Lin, Guangzhen Sun, and Xiaokai Yang (1998), "General Equilibria in Large Economies with Endogenous Structure of Division of Labor,” Working Paper, Monash University. 